\title{
CROSS-GENERA TRANSFERABILITY OF MICROSATELLITE MARKERS AND PHYLOGENETIC ASSESSMENT OF THREE SALSOLA SPECIES FROM WESTERN KAZAKHSTAN
}

\author{
Shyryn Almerekova ${ }^{1}$, Nasima Favarisova ${ }^{1}$, Yerlan Turuspekov ${ }^{1,2}$, \\ and Saule Abugalieva ${ }^{1,2, \#}$ \\ ${ }^{1}$ Institute of Plant Biology and Biotechnology, Almaty, 45 Timiryazev Str., 050040, KAZAKHSTAN \\ 2 Al-Farabi Kazakh National University, Almaty, 71 Al-Farabi Av., 050038, KAZAKHSTAN \\ \# Corresponding author, absaule@yahoo.com
}

Communicated by Isaak Rashal

\begin{abstract}
Salsola arbuscula Pall., Salsola arbusculiformis Drob. and Salsola chiwensis M. Pop. have great environmental importance as they can stabilise sand dunes and therefore are useful for desert zone landscaping. The genetic diversity and phylogenetic relationships of populations of these species collected in Western Kazakhstan were analysed using internal transcribed spacers (ITS) and simple sequence repeat (SSR) markers. The ITS sequences of species were aligned with sequences of 37 Salsola species from the NCBI. ITS analysis clustered the samples into two major groups and eight sections. The phylogenetic tree and haplotype network relationships confirmed the polyphyletic origin of Salsola and allowed taxonomic reassessment for the studied species. A set of SSR markers originally developed from genera Agriophyllum, Haloxylon, and Beta was tested for their variability in Salsola species. Twenty-six tested SSR markers were selected for their transferability scores, and 13 of them were suitable for study of genetic diversity in populations of three Salsola species. It was concluded that polymorphic SSR markers were efficient in the separation of the studied Salsola species and could be effectively used in studies related to the genetic variation in the genus.
\end{abstract}

Key words: Salsola, genetic diversity, phylogeny, ITS marker, SSR polymorphism.

\section{INTRODUCTION}

Family Chenopodiaceae Vent. is distributed worldwide, and contains more than 1500 species belonging to about 100 genera. Chenopodiaceae is one of the oldest families, the occurrence of which dates from the Upper Cretaceous. Its representatives are known to be distributed from the Arctic to tropical forests (Sukhorukov, 2007). Being predominantly classical halophytes and xerophytes, the taxa in this family are able to survive in very extreme conditions. Therefore, they often dominate in deserts, wet areas, and salt marshes along the sea coasts and the shores of saline inland continental lakes (Morenko, 2007). In Flora of Kazakhstan (Pavlov, 1960), this family is represented by 218 species of 47 genera, with Salsola L. being one of the largest genera in the family. Due to their high salt tolerance, the various members of this genus and related genera have the common name saltwort. This name comes from the Latin word salsus, meaning salty (Mosyakin, 2003).
The genus was defined and described by K. Linnaeus in Species Plantarium and divided into five species (Akopian, 2011). Ilyin developed a classification of the genus Salsola L. according to morphological characters (Komarov, 1936). A total of 120 species of the genus were described, belonging to ten sections: Kali (Adans) Ulbrich, Physurus Iljin, Brachyphylla Iljin, Heterotricha Iljin, Anchophyllum Iljin, Sphragidanthus Iljin, Caroxylon (Thunb) Iljin, Aleuranthus Iljin, Belanthera Iljin, and Coccosalsola Fenzl. According to this classification, S. arbuscula, S. arbusculiformis, and S. chiwensis belonged to the Anchophyllum section (Komarov, 1936). Bochansev (1969) distinguished 114 species in the following seven sections of the genus: Caroxylon (Thunb) Iljin, Belantera Iljin, Coccosalsola Fenzl, Malpigipila Botsch, Cardiandra Aellen, Arbuscula Ulbrich, and Salsola Kali (Popova, 2015).

According to Abdullina (1999), 33 species of Salsola grow in Kazakhstan. Many of these species are important for 
dune stabilisation, animal feeding, water conservation, and various other purposes. Among them, S. arbuscula, S. arbusculiformis, and $S$. chiwensis have high environmental importance since they perform sand-fixing and rockstrengthening functions. They are also useful for landscaping in the desert zone (Alirzayeva et al., 2015). S. arbuscula, S. gemmascens Pall., and S. rigida Pall. have been used to improve long-term pastures in sandy desert (Zwolinski et al., 2013; Toderich et al., 2016). S. arbuscula serves as winter feed for sheep and other animals and yearround feed for camels (Larin et al., 1951). Sheep and goats eat young annual shoots with leaves and fruits, and camels also feed on the thin tree branches (Toderich et al., 2016). The aboveground parts of $S$. arbuscula are applied as a dye for wool and tanning leathers. S. arbuscula and S. tragus are a useful source of fuel (Yumak et al., 2010). It is important to note that $S$. arbuscula is a widespread species in the desert regions of Central Asia (Grubov, 1980). This species was collected in Inder Lake (Western Kazakhstan) and described by Pallas (1771). S. arbusculiformis grows in Central Asia, Iran, and China (Sokolov et al., 1980). S. chiwensis is a rare endangered species (category II), which is distributed in limited areas and found in small numbers.

According to Shuiskaya and Toderich (2013), from the taxonomic point of view, the genus Salsola is one of the most complex and poorly studied. Different authors have classified $S$. arbuscula and S. arbusculiformis in different sections according to morphology. According to Bochantsev (1969), S. arbuscula and S. arbusculiformis belong to the Caroxylon section of the Arbusculae subsection, whereas Freitag (1997) attributed these two species to the Arbuscula section. Pyankov et al. (2001), using internal transcribed spacer (ITS) markers, confirmed that $S$. arbuscula and S. chiwensis belong to the Arbuscula section. According to the classification of Wen et al. (2010), based on a DNA-barcoding study using ITS and $p s b \mathrm{~B}-p s b \mathrm{H}$, these two species should be in the Kali clade. This clade combines previously separate taxa in the Salsoleae tribe: the genus Salsola sect. Kali, Salsola sect. Arbuscula, Salsola sect. Sogdiana, and the genus Traganum (Akhani et al., 2007).

Different types of DNA markers have been successfully used in the past to assess the genetic diversity of Salsola species. These studies included random amplified polymorphic DNA (RAPD) (Ryan and Ayres, 2000), inter simple sequence repeats (ISSR) (Ayres et al., 2009), amplified fragment length polymorphism (AFLP) (Abdel-Hamid, 2016), and simple sequence repeat (SSR) markers (McGray et al., 2008).

Currently, SSRs (or microsatellite) markers are one of the most commonly used types of polymerase chain reaction (PCR)-based markers that are efficient in assessing the genetic structure of populations (Westman and Kresovich, 1997; Almerekova et al., 2018). SSRs have several useful characteristics, including even distribution throughout the plant genome, codominant inheritance, and high marker reliability. In some cases, when SSR primers have not yet been developed for a specific plant species, primer sets de- signed for closely related species, genera, or members of the same family are used. These markers are used for cross-species (cross-genera) transferability or cross-species amplification. To date, a large number of studies have been carried out based on the interspecific (intergenera) portability (transferability) of SSR markers (González-Martínez et al., 2004; Dossett et al., 2009; Ekué et al., 2009; Fan et al., 2013). Transference is defined by González-Martínez et al., (2004) as the positive amplification of a PCR band of the expected size. Transferred markers (i.e. the clear amplification pattern of a single locus) were used for gene diversity and allelic richness to demonstrate their practical usefulness in genetic studies. McGray et al. (2008) analysed the genetic diversity of five Salsola species from California using SSR markers developed for Beta vulgaris, another member of the Chenopodiaceae family. The authors reported that six of twenty sugar beet SSR markers were polymorphic and useful for confirming the genetic distinctness of the analysed Salsola species. The aim of this work was to study the genetic diversity and the phylogenetic relationships of three species of Salsola (S. arbuscula, S. arbusculiformis, and $S$. chiwensis) collected in Western Kazakhstan (2015-2017), using ITS sequences and SSR markers generated from other genera of Chenopodiaceae. This study is part of a nationwide project related to the evaluation of genetic diversity in the flora of Kazakhstan using DNA markers (Turuspekov and Abugalieva 2015; Turuspekov et al., 2018).

\section{MATERIALS AND METHODS}

Plant material. Three species of Salsola were used as research material: Salsola arbuscula Pall., Salsola arbusculiformis Drob, Salsola chiwensis M. Pop. Young leaves of plants growing at least 3-5 m apart were collected in the Mangistau region (Western Kazakhstan) in 2015, 2016, 2017 (Fig. 1). The plant material of each sample was dried

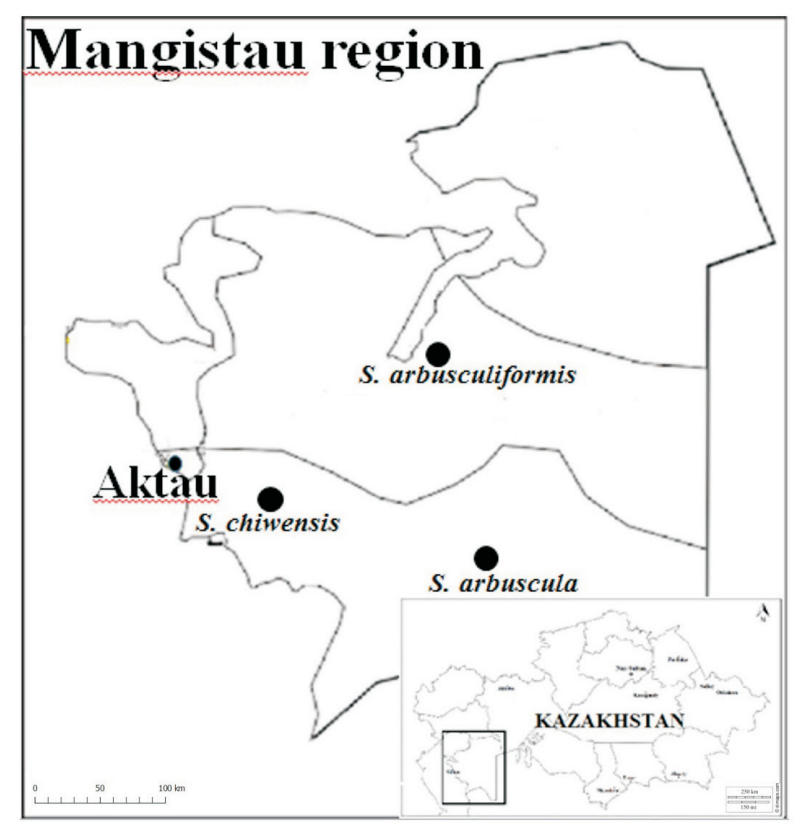

Fig. 1. Geographic location of the three Salsola species collected in the Mangistau region of Western Kazakhstan. 
in silica gel for further DNA extraction, microsatellite analysis, and barcoding. Information related to the coordinates, locations, and sizes of sampled populations of three Salsola species collected in the Mangistau region is given in Table 1 .

DNA extraction. The genomic DNA of all Salsola samples was isolated from leaves using the CTAB protocol (Doyle and Doyle, 1987). The quality and concentration of DNA were evaluated using a NanoDrop 2000 spectrophotometer (Thermo Fisher Scientific, USA) and electrophoresis in $1 \%$ agarose gels. The DNA concentration was normalised to 20 $\mathrm{ng} / \mu \mathrm{L}$ for further analysis.

DNA barcoding. The ITS-1, 5.8S, and ITS-2 regions were amplified using primers

ITS1nF (5'-AGAAGTCGTAACAAGGTTTCCGTAGG-3') and ITS4nR (5'-TCCTCCGCTTATTGATATGC-3') with an annealing temperature of $58{ }^{\circ} \mathrm{C}$ (White et al., 1990). Sequencing reactions for three plants per species were performed using the BigDye Terminator v.3.1Cycle Sequencing Kit (Applied Biosystems, USA) with the same primers, and separate forward and reversed reactions. Nucleotide sequences were analysed on an ABI 3130 DNA sequencer (Applied Biosystems, USA).

Microsatellite analysis. In total, 26 SSR markers developed from other genera of the Chenopodiaceae were tested in samples of three Salsola species. It was found that eight SSRs specific to Agriophyllum (Zhang et al., 2018), designated here as Ags, four SSRs specific to Haloxylon (Long et al., 2014), designated as $\mathrm{Hal}$, and one SSR specific to Beta (Cureton et al., 2002), designated as Bmb, were successful in the amplification of PCR products. Only 13 polymorphic SSR markers listed in Table 2 were used for the genotyping of the three Salsola species.

PCR was conducted in $20 \mu \mathrm{l}$ total volume containing $20 \mathrm{ng}$ of genomic DNA, $2.5 \mathrm{mM} \mathrm{MgCl}_{2}, 2.5 \mathrm{mM}$ of each dNTP, $2 \mathrm{mM}$ of each primer, and $1 \mathrm{U}$ Taq polymerase in the $1 \times$ TaqBuffer. PCR amplifications were performed in a thermal cycler (Veriti, Thermo Fisher Scientific, USA) for 35 cycles, consisting of denaturation at $94{ }^{\circ} \mathrm{C}$ for $30 \mathrm{~s}$, annealing for $45 \mathrm{~s}$, and elongation at $72{ }^{\circ} \mathrm{C}$ for 1 minute $30 \mathrm{~s}$. Anneal-

Table 1. Information about three Salsola species collected in the Mangistau region of Kazakhstan

\begin{tabular}{l|c|c|c|l|l}
\hline \multirow{2}{*}{ Species } & \multicolumn{2}{|c|}{ Coordinates } & Altitude (m) & \multicolumn{2}{c}{$\begin{array}{c}\text { Place of sampling } \\
\text { size }\end{array}$} \\
\cline { 2 - 4 } & latitude & longitude & & \\
\hline Salsola arbuscula & 43.29530 & 53.72569 & 92 & Mangistau region, Karakiyansky District, Western Tynybay \\
Salsola arbusculiformis & 44.13872 & 53.27211 & 110 & Mangistau region, Mangistau District \\
Salsola chiwensis & 43.60816 & 51.79219 & 117 & Mangistau region, Karakiyansky District, Karagiye Depression
\end{tabular}

Table 2. List of simple sequence repeat (SSR) markers and their corresponding primer sequences that were successful in amplification of PCR products in three Salsola species

\begin{tabular}{|c|c|c|c|c|}
\hline No. & SSR markers & Primer sequences $\left(5^{\prime}-3^{\prime}\right)$ & Motif & References \\
\hline 1 & $A g s-2$ & $\begin{array}{l}\text { F: AGCATCGGATGTGAGGAATC } \\
\text { R: TCCTTCAACTCCTCCGTGTC }\end{array}$ & $(\mathrm{CAT}) 6$ & Zhang et al., 2018 \\
\hline 2 & Ags-5 & $\begin{array}{l}\text { F: CTATGCCCATTCGTCATCCT } \\
\text { R: GGCCGTTAGCTGAGTTGAAG }\end{array}$ & (TCC)6 & Zhang et al., 2018 \\
\hline 3 & Ags-7 & $\begin{array}{l}\text { F: AGGAGCAGCAGTAGAGGCAG } \\
\text { R: CAACAGAAAAGAAGGCGGAG }\end{array}$ & $(\mathrm{AGC}) 7$ & Zhang et al., 2018 \\
\hline 4 & Ags-9 & $\begin{array}{l}\text { F: CAAGTTTTAATCTTTTAGCACCCTTT } \\
\text { R: CCCCСTTTTCССТCTTTCTA }\end{array}$ & $(\mathrm{AGA}) 7$ & Zhang et al., 2018 \\
\hline 5 & Ags-21 & $\begin{array}{l}\text { F: TCСТTCСССТСТСАССТTCT } \\
\text { R: TGTTTGGGAGGAGAAACTGG }\end{array}$ & (TGTA)5 & Zhang et al., 2018 \\
\hline 6 & Ags-22 & $\begin{array}{l}\text { F: AGTGGTGTTTGTTGCTGCTG } \\
\text { R: ACTCCCTCACCССTCACTCT }\end{array}$ & $(\mathrm{CTTT}) 5$ & Zhang et al., 2018 \\
\hline 7 & Ags-23 & $\begin{array}{l}\text { F: CAATGGGGTTTGAGCATTTC } \\
\text { R: TTCCGGATGAATGATGGAAT }\end{array}$ & (ATTA)6 & Zhang et al., 2018 \\
\hline 8 & Ags-29 & $\begin{array}{l}\text { F: TAAGTTCATCCTTGGCCCAT } \\
\text { R: CCTCTTGCTGGACATGTGTTT }\end{array}$ & $(\mathrm{CA}) 6(\mathrm{AAT}) 5$ & Zhang et al., 2018 \\
\hline 9 & Hal34975 & $\begin{array}{l}\text { F: AACTCGCCCATTATTGCACG } \\
\text { R: AGAGGGTCAACGTCGTCAAC }\end{array}$ & N/A & Long et al., 2014 \\
\hline 10 & Hal42802 & $\begin{array}{l}\text { F: AACCCTAGAAAGCTTCGCCC } \\
\text { R: TTTGGGAAAGCAGCGGAGAT }\end{array}$ & N/A & Long et al, 2014 \\
\hline 11 & Hal45535 & $\begin{array}{l}\text { F: AACATCAACAGCGCCCACTA } \\
\text { R: GGCCTATGATGCTGCACTCT }\end{array}$ & N/A & Long et al., 2014 \\
\hline 12 & Hal47234 & $\begin{array}{l}\text { F: AACACAACATCCGCACCTCA } \\
\text { R: GGATTTGGGTACGGGTCAGG }\end{array}$ & N/A & Long et al., 2014 \\
\hline 13 & Bmb3 & $\begin{array}{l}\text { F: CGGTTGCAAGTCGATAAGGT } \\
\text { R: CCGGTTGAACAGCAGAACAGG }\end{array}$ & (CA)42 & Cureton et al., 2002 \\
\hline
\end{tabular}


ing temperatures were individually optimised for each primer pair and varied from $43{ }^{\circ} \mathrm{C}$ to $58{ }^{\circ} \mathrm{C}$. After the cycles, a final $10 \mathrm{~min}$ extension period at $72{ }^{\circ} \mathrm{C}$ was included.

The amplified fragments were separated on polyacrylamide gels $(6 \%)$ using $0.5 \times$ Tris-borate-EDTA (TBE buffer). The gels were stained with ethidium bromide and visualised in the gel documentation system Gel Doc XR+ (Bio-Rad, USA). Polymorphism was subjected to visual screening, and SSR markers were evaluated as codominant.

Statistical analysis. ITS nucleotide sequences of the three Salsola species collected in Kazakhstan were aligned with 39 sequences of other species obtained from the NCBI database, including two outgroup species - Atriplex prostrata and Atriplex rosea. MEGA 7 software (Kumar et al., 2016) was used. The phylogenetic tree was reconstructed using the Neighbor-Joining (NJ) method (Saitou and Nei, 1987) with 1000 bootstrap replications. Haplotype diversity (Hd) and nucleotide diversity $(\pi)$ were estimated in DnaSP6 (Rozas et al., 2017). Haplotype analyses were calculated using the Neighbor Net algorithm in the SplitsTree4 software (Huson and Bryant, 2006).

The PopGen32 (Yeh et al., 1997) and GenAlex 6.5 (Peakall and Smouse, 2006; 2012) software were used to assess the genetic diversity of the three Salsola species. Nei's genetic diversity index, number of alleles per locus, and the number of effective alleles were calculated in PopGen32.

The polymorphism information content (PIC) was calculated according to Botstein et al., (1980).

The genetic distances between the three Salsola species were determined using pairwise Nei's genetic distances in the GenAlex version 6.5 software (Peakall and Smouse, 2016). Genetic differentiation within populations and between species of Salsola was evaluated using analysis of molecular variance (AMOVA) in GenAlEx. Construction of the phylogenetic tree was performed using PAST software version 3.26 (Hammer et al., 2001). Principal component analysis (PCA) plot swas obtained using the ClustVist web tool (Metsalu and Vilo, 2015).

\section{RESULTS}

Phylogeny of Salsola species based on ITS sequences. The alignment of ITS sequences in three accessions per species collected in Kazakhstan revealed no intraspecies polymorphism. The nucleotide sequences of ITS in single accessions of $S$. arbuscula, S. arbusculiformis, and S. chiwensis were submitted to NCBI GenBank (Table 3). They were aligned together with sequences of 37 Salsola references from NCBI, while Atriplex prostrata and Atriplex rosea were chosen as outgroup species. The aligned length of the ITS sequences was $631 \mathrm{bp}$; the aligned length was increased to $635 \mathrm{bp}$ with outgroup species. Among the 631 aligned entire ITS sites of the 40 Salsola samples, 390 (61.8\%) were variable and 138 were parsimony informative. There were polymorphic sites at 172 bases $(27.2 \%)$ in ITS1, 17
Table 3. The haplotype distribution in Salsola and outgroup species

\begin{tabular}{|c|c|c|c|}
\hline Haplotype & $\begin{array}{c}\text { Number of } \\
\text { species }\end{array}$ & $\begin{array}{c}\text { NCBI accession } \\
\text { number }\end{array}$ & Species \\
\hline Hap 1 & 1 & МT393878.1 & Salsola arbuscula \\
\hline Hap 2 & 1 & HM131645.1 & Salsola arbuscula \\
\hline \multirow[t]{2}{*}{ Hap 3} & 2 & MT393879.1 & Salsola arbusculiformis \\
\hline & & KC310717.1 & Salsola arbusculiformis \\
\hline Hap 4 & 1 & MT393880.1 & Salsola chiwensis \\
\hline Hap 5 & 1 & AF318642.1 & Salsola chiwensis \\
\hline Hap 6 & 1 & HM131651.1 & Salsola foliosa \\
\hline Hap 7 & 1 & HM131649.1 & Salsola collina \\
\hline Hap 8 & 1 & EU643790.1 & Salsola soda \\
\hline Hap 9 & 1 & KX262574.1 & Salsola zygophylloides \\
\hline \multirow[t]{2}{*}{ Hap 10} & 2 & HM131652.1 & Salsola tragus \\
\hline & & MF063463.1 & Salsola komarovii \\
\hline Hap 11 & 1 & HM131663.1 & Salsola paulsenii \\
\hline Hap 12 & 1 & EF453472.1 & Salsola dendroides \\
\hline Hap 13 & 1 & EF453500.1 & Salsola tomentosa \\
\hline Hap 14 & 1 & HM131661.1 & Salsola nitraria \\
\hline Hap 15 & 1 & HM131662.1 & Salsola orientalis \\
\hline Hap 16 & 1 & EF453494.1 & Salsola richteri \\
\hline Hap 17 & 1 & EF453464.1 & Salsola abarghuensis \\
\hline Hap 18 & 1 & EF453461.1 & Salsola araneosa \\
\hline Hap 19 & 1 & EF453514.1 & Salsola carpatha \\
\hline Hap 20 & 1 & EF453471.1 & Salsola cyclophylla \\
\hline Hap 21 & 1 & EF453477.1 & Salsola forcipitata \\
\hline Hap 22 & 1 & EF453479.1 & Salsola glabrescens \\
\hline Hap 23 & 1 & AF318630.1 & Salsola incanescens \\
\hline Hap 24 & 1 & EU643789.1 & Salsola kali \\
\hline Hap 25 & 1 & EF453498.1 & Salsola zehzadii \\
\hline Hap 26 & 1 & EF453465.1 & Salsola inermis \\
\hline Hap 27 & 1 & EF453486.1 & Salsola kerneri \\
\hline Hap 28 & 1 & EF453475.1 & Salsola drummondii \\
\hline Hap 29 & 1 & EF453501.1 & Salsola vermiculata \\
\hline Hap 30 & 1 & EF453481.1 & Salsola gossypina \\
\hline Hap 31 & 1 & EF453462.1 & Salsola vvedenskyi \\
\hline Hap 32 & 1 & EF453473.1 & Salsola deserticola \\
\hline Hap 33 & 1 & HM131644.1 & Salsola aperta \\
\hline Hap 34 & 1 & KC310722.1 & Salsola laricifolia \\
\hline Hap 35 & 1 & KX262569.1 & Salsola divaricate \\
\hline Hap 36 & 1 & KX262552.1 & Salsola botschantzevii \\
\hline Hap 37 & 1 & EF453490.1 & Salsola montana \\
\hline Hap 38 & 1 & KX262598.1 & Salsola oreophila \\
\hline Hap 39 & 1 & HM005856.1 & Atriplex prostrata \\
\hline Hap 40 & 1 & HM005858.1 & Atriplex rosea \\
\hline
\end{tabular}

Species collected in Kazakhstan are highlighted in bold. Data for remaining species were acquired from the NCBI database

bases $(2.7 \%)$ in the $5.8 \mathrm{~S}$ region, and the most polymorphic region was ITS2, with 201 bases (31.8\%). The aligned sequences of the Salsola and outgroup species were used to generate the NJ phylogenetic tree (Fig. 2).

Salsola species in the NJ phylogenetic tree were basally resolved into two main clades belonging to the tribes Salsoleae and Caroxyloneae. The first clade Caroxyloneae in- 


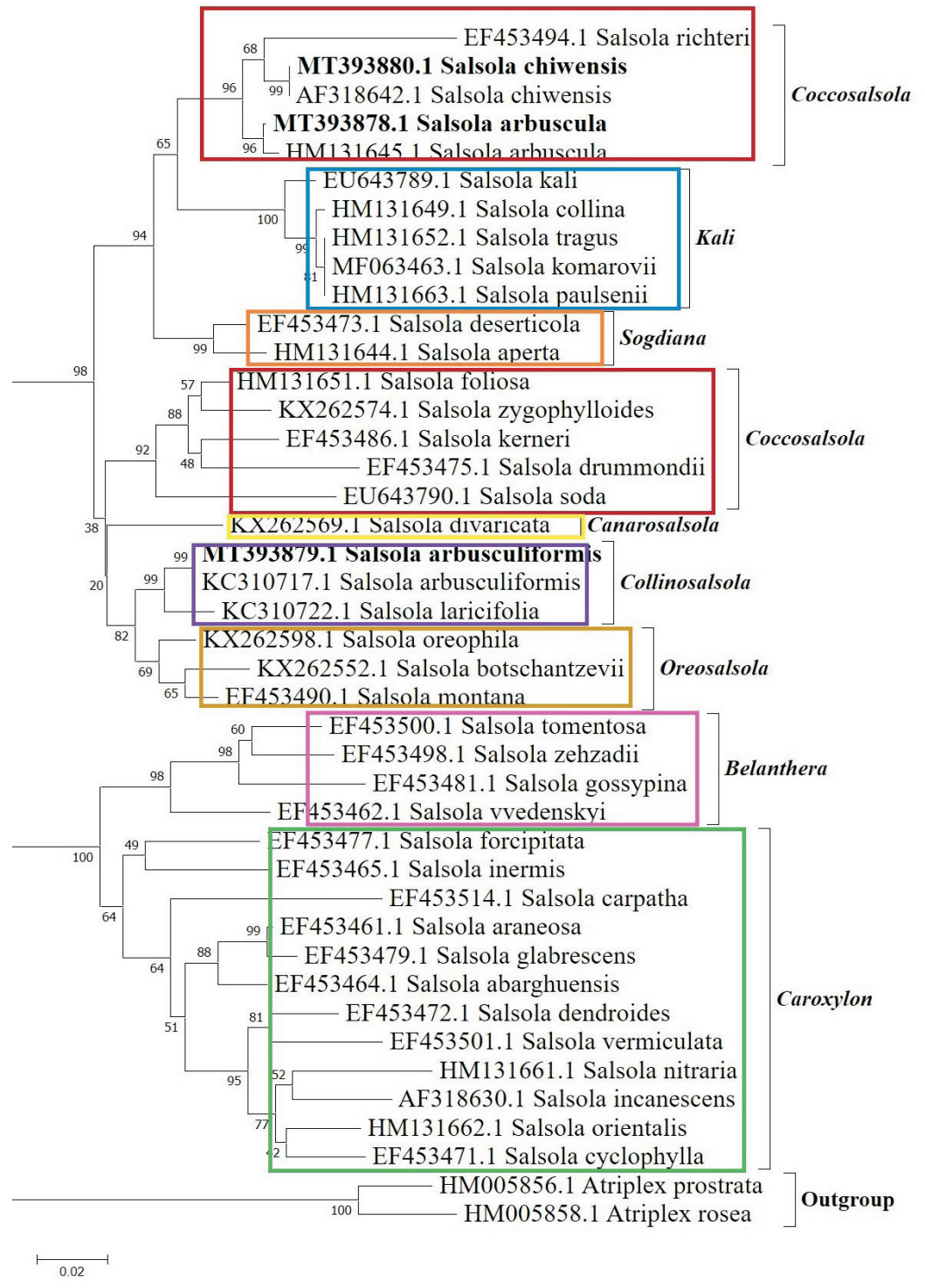

Fig. 2. Neighbor-Joining (NJ) phylogenetic tree inferred from the internal transcribed spacer (ITS) region of Salsola. The node numbers indicate the bootstrap value of NJ. Species collected in Kazakhstan are highlighted in bold. The names of the genus sections are given according to Akhani et al. (2007). cluded species from the sections Caroxylon (Thungb.) Fenzl and Belanthera Iljin. The second major clade contained species from Coccosalsola, Canarosalsola, Oreosalsola, Collinosalsola, Sogdiana, and Kali sections that belong to the Salsoleae tribe. The species $S$. arbuscula, S. arbusculiformis, and S. chiwensis collected in Western Kazakhstan were grouped with the representatives of the Salsoleae tribe. $S$. arbusculiformis was grouped together with S. laricifolia, which corresponded to the section Collinosalsola. S. arbuscula and S. chiwensis, and together with the references of the representatives of the same two species from GenBank and S. richteri, formed a subclade of the Coccosalsola section (Fig. 2).

The Neighbor Net analysis based on ITS sequences. Neighbor Net analysis was carried out by converting ITS sequences into haplotypes. Relationships among the haplotypes are represented by a network diagram or splits graph (Fig. 3). Neighbor Net analysis identified two major clades corresponding to clades in the topology of the tree reconstructed using the NJ method. haplotypes were identified for the ITS region in Salsola and outgroup accessions in the splits graph analysis, where the haplotype diversity (Hd) was 0.9977 and nucleotide diversity $(\pi)$ was 0.1268 , respectively (Fig. 3).

The splits graph of haplotypes separated the Salsola accessions into Salsoleae and Caroxyloneae tribes. The haplotype distribution information is presented in Table 3. The three Salsola species collected in Kazakhstan, S. arbuscula, S. arbusculiformis, and $S$. chiwensis, formed the three haplotypes Hap 1, Hap 3, and Hap 4, respectively (Fig. 3, Table 3).

Two haplotypes were found within a single species, and some closely related species share the same haplotype. For example, two haplotypes were found in S. arbuscula (Hap 1 and Hap 2) and in S. chiwensis (Hap 4 and Hap 5). S. tragus, S. komarovii (Hap 10), and two accessions of $S$. arbusculiformis (Hap 3), share the same haplotypes.

Genetic diversity of three Salsola species based on microsatellite analysis.

Twenty-six SSR markers developed earlier for Agriophyllum, Haloxylon, and Beta genera were tested in samples 


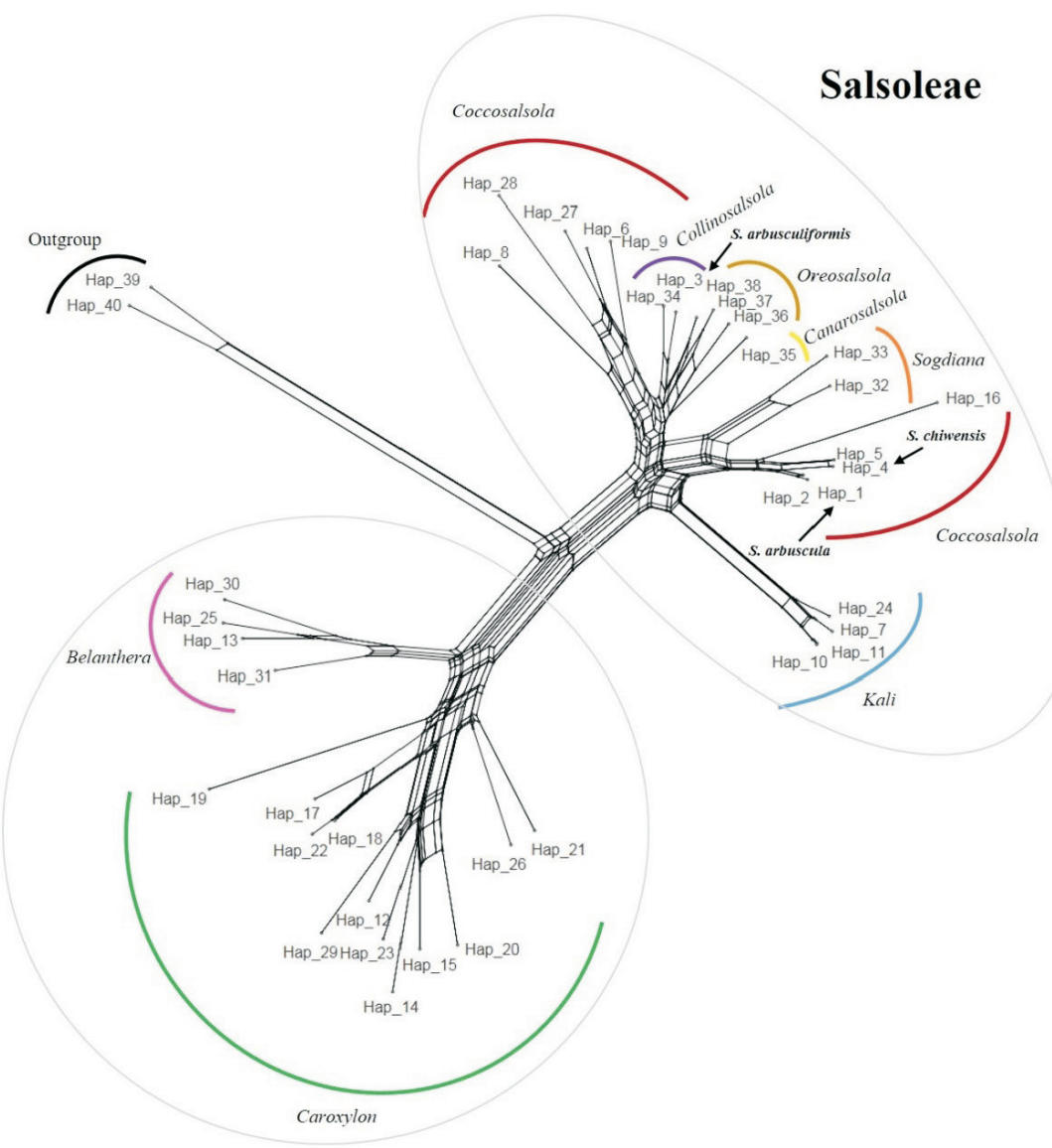

Caroxyloneae
Fig. 3. Neighbor Net analysis of Salsola and outgroup species based on ITS sequence data. The names of the genus sections are given according to Akhani et al. (2007). of three Salsola species, S. arbuscula, S. arbusculiformis, and $S$. chiwensis from Kazakhstan. Thirteen SSRs, including eight markers specific to Agriophyllum, four SSRs of Haloxylon and one for Beta, were polymorphic markers and allowed the successful discrimination of the collection consisting of three populations of different Salsola species (Table 4). Three of eight Agriophyllum markers (Ags-3, Ags-21, and $A g s-23$ ) showed cross-genera amplification with the exact expected band sizes. This indicates that primer-binding sites between the two related Chenopodiaceae genera, Agriophyllum and Salsola, were fairly well conserved. Another two SSR markers generated in Haloxylon (Hal45535 and Hal47234) exhibited a cross- genera amplification ability. In general, the assessment of thirteen SSR markers allowed the elucidation of 22 polymorphic loci that generated 70 alleles in three species of Salsola (Table 5). The assessment of those 22 polymorphic loci showed that eight of those loci for seven markers (Ags-7.2, Ags-9.1, Ags-9.2, Ags-21, Ags-23, Ags-29.1, Hal 34975.1, Hal 42802.2) were polymorphic in $S$. arbuscula, fourteen loci of eleven markers (Ags-3, Ags-5, Ags-7.1, Ags-7.2, Ags-7.3, Ags-9.1, Ags-9.2, Ags-21, Ags-22, Ags-23, Ags-29.2, Hal 42802.1, Hal 47234, Bmb3.2) were polymorphic in $S$. arbusculiformis, and nine loci of seven markers (Ags-9.1, Ags-9.2, Ags-22, Ags-29.1, Hal 34975.1, Hal 45535.1, Hal 45535.2, Bmb3.1, Bmb3.2) in S. chiwensis (Table 5). The number of effective alleles varied from 1.2 (Ags-7-1, $B m b 3.1)$ to 3.3 (Ags-22), with an average of 2.2. There were
Table 4. Number of SSR markers developed in the genera Agriophyllum, Haloxylon, and Beta

\begin{tabular}{|c|c|c|c|c|c|c|}
\hline \multirow[b]{2}{*}{ Genus } & \multirow{2}{*}{$\begin{array}{c}\text { Total } \\
\text { number } \\
\text { of } \\
\text { SSRs }\end{array}$} & \multirow{2}{*}{$\begin{array}{l}\text { Positive } \\
\text { amplifi- } \\
\text { cation }\end{array}$} & \multirow{2}{*}{$\begin{array}{c}\text { Poly- } \\
\text { morphic } \\
\text { SSRs }\end{array}$} & \multicolumn{3}{|c|}{ Polymorphic SSRs by species } \\
\hline & & & & $\begin{array}{c}S . \\
\text { arbuscula }\end{array}$ & $\begin{array}{c}S . \\
\text { arbusculifo } \\
\text { rmis }\end{array}$ & $\begin{array}{c}S . \\
\text { chiwensis }\end{array}$ \\
\hline $\begin{array}{l}\text { Agrio- } \\
\text { phyllum }\end{array}$ & 15 & 10 & 8 & 5 & 8 & 2 \\
\hline Haloxylon & 5 & 4 & 4 & 2 & 2 & 3 \\
\hline Beta & 6 & 1 & 1 & 0 & 1 & 1 \\
\hline
\end{tabular}

found to be 6, 23, and 9 private alleles in $S$. arbuscula, $S$. arbusculiformis, and $S$. chiwensis, respectively. The average number of private alleles per species (population) was $0.273,1.045$, and 0.409 in $S$. arbuscula, S. arbusculiformis, and $S$. chiwensis, respectively. The average values of Nei's genetic diversity index for each species were 0.12 for $S$. arbuscula, 0.25 for $S$. arbusculiformis, and 0.18 for $S$. chiwensis, and the average index for all three species was 0.52 (Table 5). Thus, the most polymorphism was observed within the population of $S$. arbusculiformis.

The polymorphism information index (PIC) in identified loci ranged from 0.15 (Ags-7.1) to 0.65 (Ags-7.3), with an average value of 0.44 across all loci. PIC values suggest that eight loci were highly informative (PIC $\geq 0.5$ ), twelve loci were moderately informative $(0.5>$ PIC $>0.25)$, and 
Table 5. Genetic diversity of 22 microsatellite loci in three species of Salsola from Western Kazakhstan.

\begin{tabular}{|c|c|c|c|c|c|c|c|c|c|c|c|c|c|c|c|c|}
\hline \multirow[t]{2}{*}{ Locus } & \multicolumn{4}{|c|}{ S. arbuscula } & \multicolumn{4}{|c|}{ S. arbusculiformis } & \multicolumn{4}{|c|}{ S. chiwensis } & \multicolumn{4}{|c|}{ Total } \\
\hline & na & ne & Nei & PIC & na & ne & Nei & PIC & na & ne & Nei & PIC & na & ne & Nei & PIC \\
\hline$A g s-3$ & 1 & 1.00 & 0 & 0 & 2 & 1.95 & 0.488 & 0.369 & 1 & 1.00 & 0 & 0 & 3 & 2.30 & 0.561 & 0.499 \\
\hline Ags-7.1 & 1 & 1.00 & 0 & 0 & 2 & 1.50 & 0.332 & 0.277 & 1 & 1.00 & 0 & 0 & 2 & 1.20 & 0.162 & 0.149 \\
\hline Ags-7.2 & 3 & 1.91 & 0.475 & 0.403 & 2 & 1.36 & 0.266 & 0.231 & 1 & 1.00 & 0 & 0 & 4 & 2.30 & 0.556 & 0.511 \\
\hline Ags-7.3 & 1 & 1.00 & 0 & 0 & 3 & 1.99 & 0.499 & 0.416 & 1 & 1.00 & 0 & 0 & 4 & 3.30 & 0.701 & 0.650 \\
\hline Ags-9.1 & 2 & 1.12 & 0.105 & 1.00 & 3 & 1.38 & 0.277 & 0.257 & 4 & 2.38 & 0.580 & 0.535 & 4 & 2.40 & 0.589 & 0.505 \\
\hline Ags-9.2 & 2 & 1.12 & 0.105 & 0.100 & 2 & 1.87 & 0.465 & 0.357 & 2 & 1.22 & 0.180 & 0.164 & 3 & 1.50 & 0.322 & 0.291 \\
\hline$A g s-21$ & 2 & 1.71 & 0.415 & 0.329 & 4 & 2.71 & 0.632 & 0.578 & 1 & 1.00 & 0 & 0 & 5 & 2.90 & 0.655 & 0.613 \\
\hline$A g s-22$ & 1 & 1.00 & 0 & 0 & 3 & 2.33 & 0.571 & 0.504 & 2 & 2.00 & 0.500 & 0.375 & 4 & 3.30 & 0.697 & 0.641 \\
\hline Ags-23 & 3 & 2.72 & 0.633 & 0.556 & 3 & 1.91 & 0.475 & 0.404 & 1 & 1.00 & 0 & 0 & 4 & 2.40 & 0.581 & 0.491 \\
\hline Ags-29.1 & 2 & 1.64 & 0.389 & 0.314 & 1 & 1.00 & 0 & 0 & 2 & 1.10 & 0.095 & 0.091 & 3 & 2.40 & 0.589 & 0.501 \\
\hline Hal 34975.1 & 2 & 1.38 & 0.278 & 0.239 & 1 & 1.00 & 0 & 0 & 2 & 1.47 & 0.320 & 0.269 & 2 & 2.00 & 0.500 & 0.375 \\
\hline Hal 34975.2 & 1 & 1.00 & 0 & 0 & 1 & 1.00 & 0 & 0 & 1 & 1.00 & 0 & 0 & 2 & 1.90 & 0.473 & 0.361 \\
\hline Hal 42802.1 & 1 & 1.00 & 0 & 0 & 2 & 1.63 & 0.388 & 0.313 & 1 & 1.00 & 0 & 0 & 3 & 2.20 & 0.545 & 0.472 \\
\hline Hal 42802.2 & 2 & 1.25 & 0.198 & 0.178 & 1 & 1.00 & 0 & 0 & 1 & 1.00 & 0 & 0 & 2 & 2.00 & 0.494 & 0.372 \\
\hline Hal 42802.3 & 1 & 1.00 & 0 & 0 & 1 & 1.00 & 0 & 0 & 1 & 1.00 & 0 & 0 & 2 & 1.90 & 0.473 & 0.361 \\
\hline Hal 45535.1 & 1 & 1.00 & 0 & 0 & 1 & 1.00 & 0 & 0 & 2 & 1.91 & 0.475 & 0.363 & 3 & 2.50 & 0.597 & 0.511 \\
\hline Hal 45535.2 & 1 & 1.00 & 0 & 0 & 1 & 1.00 & 0 & 0 & 2 & 1.80 & 0.444 & 0.346 & 2 & 2.00 & 0.496 & 0.373 \\
\hline Hal 47234 & 1 & 1.00 & 0 & 0 & 2 & 1.36 & 0.266 & 0.231 & 2 & 1.47 & 0.320 & 0.269 & 4 & 2.30 & 0.572 & 0.496 \\
\hline Bmb3.1 & 1 & 1.00 & 0 & 0 & 1 & 1.00 & 0 & 0 & 3 & 2.17 & 0.540 & 0.466 & 3 & 1.20 & 0.158 & 0.151 \\
\hline Bmb3.2 & 1 & 1.00 & 0 & 0 & 2 & 1.63 & 0.388 & 0.313 & 3 & 2.17 & 0.540 & 0.466 & 5 & 2.90 & 0.651 & 0.595 \\
\hline Mean & 1.46 & 1.22 & 0.118 & 0.101 & 1.96 & 1.48 & 0.253 & 0.215 & 1.64 & 1.35 & 0.182 & 0.146 & 3.20 & 2.20 & 0.517 & 0.443 \\
\hline SE & 0.14 & 0.09 & 0.041 & 0.035 & 0.19 & 0.11 & 0.048 & 0.041 & 0.18 & 0.10 & 0.049 & 0.043 & 0.96 & 0.56 & 0.143 & 0.136 \\
\hline
\end{tabular}

na, number of alleles per locus; ne, number of effective alleles; Nei, Nei's genetic diversity index; PIC, polymorphism information content; SE, standard error

two loci were less informative (PIC $\leq 0.25$ ) (Table 5). The AMOVA test, using genetic distances of the three Salsola species based 22 SSR loci, showed that of total genetic diversity, $72 \%$ of the variation was between species, and $28 \%$ was within species. Principal component analysis (PCA) showed that PC1 $(38.9 \%)$ differentiated S. arbusculiformis from the remaining two species, and PC2 (13.7\%) separated S. arbuscula from S. chiwensis (Fig. 4).

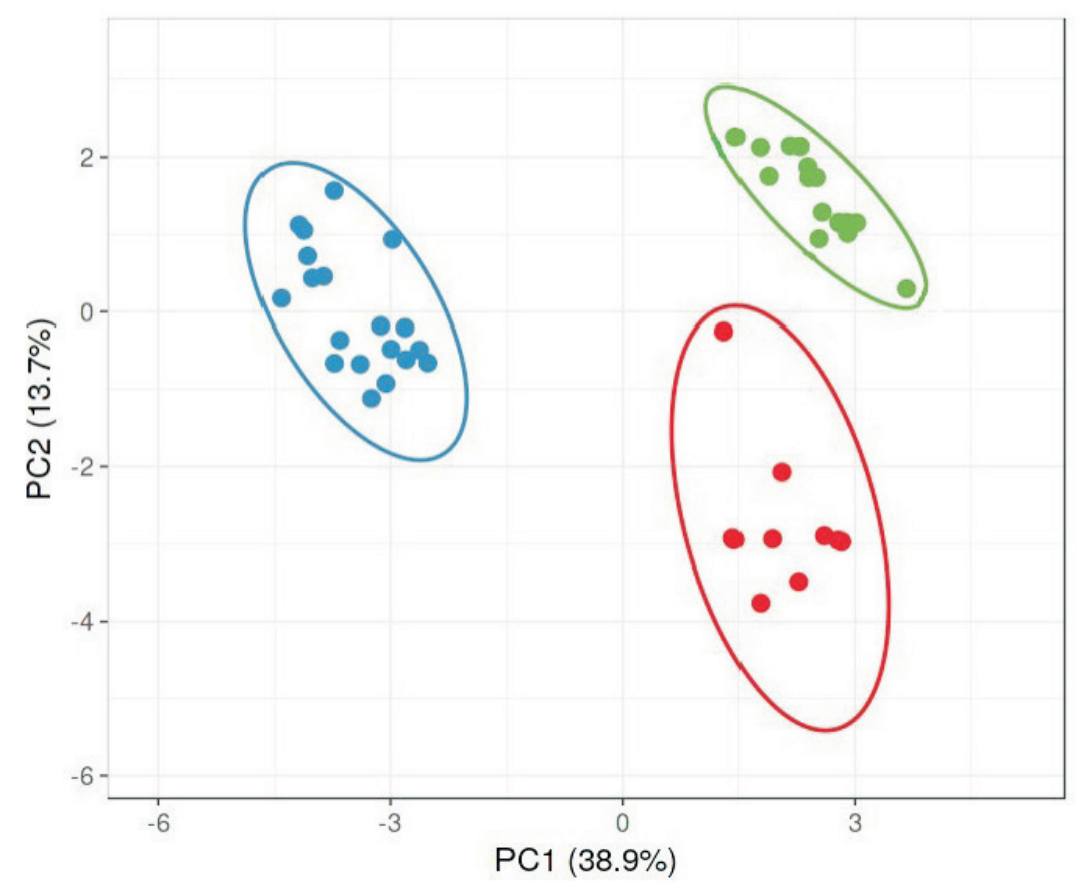

\section{Species}

Salsola chiwensis M.Pop.

Salsola arbusculiformis Drob.

Salsola arbuscula Pall. 


\section{DISCUSSION}

Literature survey showed that the molecular phylogenetic positions of the three studied species in the Salsola clade are still controversial. For instance, Wen et al. (2010) suggested that $S$. arbuscula and $S$. chiwensis belong to section Kali, while Akhani et al., (2007) attributed them to section Coccosalsola. Another uncertainty is the position of $S$. arbusculiformis, as Akhani et al. (2007) suggested that it is part of the section Collinosalsola, whereas in Akhani et al. (2016), the same group of co-authors claimed that the species might belong to the clade Oreosalsola. In the latter case, the attribution of $S$. arbusculiformis to the clade Oreosalsola was advised based on morphological features, environmental conditions of growth, ITS sequence alignment, and photosynthetic types of plants (Akhani et al., 2016). In this work, based on the ITS sequence alignment of three local species and 37 samples from the NCBI database, we confirm the clustering of studied taxa given by Akhani et al. (2007). The NJ phylogenetic tree suggested that Salsolaleae clade was divided into six sections, namely, Coccosalsola, Canarosalsola, Oreosalsola, Collinosalsola, Sogdiana, and Kali (Figs. 2 and 3). Interestingly, the phylogenetic tree and network divided Coccosalsola into two subgroups, which could potentially lead to further elaboration of the taxonomy in this section. Two local species, $S$. arbuscula and $S$. chiwensis, were attributed to the section Coccosalsola, while $S$. arbusculiformis was placed within the section Collinosalsola. The network profile (Fig. 4) suggests that species in Collinosalsola, Oreosalsola, and Canarosalsola have a high level of relatedness and can be united in a single section, which is in partial accordance with the proposition by Akahani et al., (2016).

The analyses of ITS alignment suggested that ITS2 has 201 polymorphic sites, followed by ITS1 (172 sites), and 5.8S (17 sites) of 631 nucleotides. Several previously published reports indicated the effectiveness of implication of ITS2 in molecular evolution and species identification (Qin et al., 2017; Yu et al., 2017). The obtained results in this work confirmed that ITS2 is a very informative region for DNA barcoding applications in plants (Chen et al., 2010).

Recently, a number of reports indicated that SSR markers generated in one species could be successfully used for genetic diversity studies in other species of the same genus (Chagné et al., 2004; Giraldo et al., 2005; Feng et al., 2009), or even in species of different genera of the same family (Ekué et al., 2009; Gasic et al., 2009; Fan et al., 2013). These microsatellite markers have cross-species (cross-genera) transferability or cross-species amplification abilities. Such abilities of microsatellite markers could be directly used in genetic diversity studies in the species of the genus Salsola, where there is still a lack of developed SSR markers. The transferability rates of SSRs originally developed in A. squarrosum and $H$. ammodendron in three Salsola species were $20 \%$ and $40 \%$, respectively. Our results suggested that eight of ten SSRs from Agriophyllum, and four of five SSRs from Haloxylon, were polymorphic in Salsola (Table 4). The first attempt of using the cross-genera amplification in Salsola was carried out using the 20 previously reported Beta SSR markers (McGray et al., 2008). The results suggested that the six markers were polymorphic in five genetically distinct Salsola taxa. In this study, the SSR analysis results suggested that only one (Bmb3) of six tested SSRs of B. vulgaris had this polymorphism. Overall, the high level of polymorphism and good transferability of SSRs from related genera to Salsola species indicated their usefulness for application in future molecular screening and comparative genomic studies among Salsola and other Chenopodiaceae species.

\section{CONCLUSION}

The application of ITS allowed the separation of the analysed Salsola species into two main clades, which correspond with the Salsoleae and Caroxyloneae tribes. The generated phylogenetic tree and haplotype network were well in congruence with existing phylogenetic classifications. Two local species, S. arbuscula and S. chiwensis, were attributed to the section Coccosalsola, while S. arbusculiformis was placed within the section Collinosalsola. The results confirmed the polyphyletic origin of the genus.

The study revealed that 13 of 26 SSR markers, which originated from the genera Agriophyllum, Haloxylon, and Beta were polymorphic in three studied species of Salsola. The results showed that eight SSR loci were highly informative for the analysed populations, with PIC values ranging from 0.501 to 0.650 . In the Principal Component Analysis (PCA), component 1 effectively separated $S$. arbusculiformis from $S$. arbuscula and $S$. chiwensis, while component 2 divided $S$. arbuscula from $S$. chiwensis. The obtained results indicated high transferability of SSR markers generated in Agriophyllum, Haloxylon, and Beta in the differentiation of three Salsola taxa from Western Kazakhstan.

\section{ACKNOWLEDGMENTS}

The research on microsatellite analysis was conducted within the framework of the project "Key techniques for sand Dune Stabilization and Vegetation Recovery in the typical regions of the countries along the Silk Road Economic Belt" (REF: 2016YFE0203400) supported by the Ministry of Science and Technology of China. DNA barcoding using ITS marker was carried out within the grant AP05131621 "Informational system for molecular genetic and botanical documentation of wild flora in Kazakhstan" supported by the Ministry of Education and Science of the Republic of Kazakhstan. The authors are grateful to Dr. A. Imanbayeva (Mangyshlak Experimental Botanical Garden) for sampling populations of Salsola species in Western Kazakhstan in the framework of the Research Programme 0237 (2015-2017) coordinated by the Institute of Plant Biology and Biotechnology.

\section{REFERENCES}

Anonymous (2018). The Sixth National Report of Biological Diversity in the Republic of Kazakhstan. Astana. 227 pp. Available at: https://www.cbd.int/doc/nr/nr-06/kz-nr-06-en.pdf 
Abdel-Hamid, A. M. E. (2016). Characterization of four Salsola species and their genetic relationship by AFLP. Pak. J. Bot., 48 (3), 1183-1187.

Abdulina, S. A. (1999). Checklist of Vascular Plants in Kazakhstan. Almaty. 187 pp.

Akhani, H., Edwards, G., Roalson, E. H. (2007). Diversification of the Old World Salsoleae s.l. (Chenopodiaceae): Molecular phylogenetic analysis of nuclear and chloroplast data sets and a revised classification. Int. J. Plant. Sci., 168 (6), 931-956.

Akhani, H., Khoshravesh, R., Malekmohammadi, M. (2016). Taxonomic novelties from Irano-Turanian region and NE Iran: Oreosalsola, a new segregate from Salsola sl, two new species in Anabasis and Salvia, and two new combinations in Caroxylon and Sesel. Phytotaxa, 249 (1), 159-180.

Akopian, J. A. (2011). Genus Salsola L. sensu lato (Chenopodiaceae) in South Transcaucasia [Акопян Ж. А. Род Salsola sensu lato (Chenopodiaceae) в Южном Закавказье]. Takhtajania [Taxтаджяния], 1, 124-132 (in Russian).

Alirzayeva, E., Ali-zade, V., Shirvani, T., Toderich, K. (2015). Evaluation of wild halophytes of Aralo-Caspian flora towards soil restoration and food security improvement. In: Öztürk, M., Ashraf, M., Aksoy, A., Ahmad, M., Hakeem., K. (eds.) Plants, Pollutants and Remediation. Springer, Dordrecht, pp. 63-98.

Almerekova, S., Lisztes-Szabo, Zs., Mukhitdinov, N., Kurmanbayeva, M., Abidkulova, K., Sramko, G. (2018). Genetic diversity and population genetic structure of the endangered Kazakh endemic Oxytropis almaatensis (Fabaceae). Acta Bot. Hung., 60 (3-4), 263-278.

Ayres, D., Ryan, F.J., Grotkopp, E., Bailey, J., Gaskin, J. (2009). Tumbleweed (Salsola, section Kali) species and speciation in California. Biol. Invasions, 11 (5), 1175-1187.

Bochantsev, V. P. (1969). Genus Salsola L., a brief history of its development and settlement [Бочанцев В. П. Род Salsola L., краткая история его развития и расселения]. Bot. J. [Бот. журн.], 54 (7), 989-1001 (in Russian)

Botstein, D., White, R. L., Skolnick, M., Daviset, R. W. (1980). Construction of a genetic linkage map in man using restriction fragment length polymorphisms. Amer. J. Hum. Genet., 32 (3), 314-331.

Chagné, D., Chaumeil, P., Ramboer, A., Collada, C., Guevara, A., Cervera, M. T., Vendramin, G. G., Garcia, V., Frigerio, J. M., Echt, C., Richardson, T., Plomion, C. (2004). Cross-species transferability and mapping of genomic and cDNA SSRs in pines. Theor. Appl. Genet., 109 (6), 1204-1214.

Chen, S., Yao, H., Han, J., Liu, C., Song, J., Shi, L., Zhu, Y., Ma, X., Gao, T., Pang, X, Luo, K., Li, Y., Li, X., Jia, X., Lin, Y., Leon, C. (2010). Validation of the ITS2 region as a novel DNA barcode for identifying medicinal plant species. PloS One, 5 (1), e8613.

Cureton, A. N., Burns, M. J., Ford-Lloyd, B. V., Newbury, H. J. (2002). Development of simple sequence repeat (SSR) markers for the assessment of gene flow between sea beet (Beta vulgaris ssp. maritima) populations. Mol. Ecol. Notes., 2 (4), 402-403.

Dossett, M., Bassil, N. V., Finn, C. E. (2009). Transferability of Rubus microsatellite markers for use in black raspberry. HortScience, 44, 103-109.

Doyle, J. J., Doyle, J. L. (1987). A rapid DNA isolation procedure for small quantities of fresh leaf tissue. Phytochem. Bull., 19 (1), 11-15.

Ekué, M. R. M., Gailing, O., Finkeldey, R. (2009). Transferability of simple sequence repeat (SSR) markers developed in Litchi chinensis to Blighia sapida (Sapindaceae). Plant Mol. Biol. Rep., 27 (4), 570.

Fan, L., Zhang, M. Y., Liu, Q. Z., Li, L. T., Song, Y., Wang, L. F., Zhang, S. L., Wu, J. (2013). Transferability of newly developed pear SSR markers to other Rosaceae species. Plant Mol. Biol. Rep. 31 (6), 1271-1282.

Feng, S. P., Li, W. G., Huang, H. S., Wang, J. Y., Wu, Y. T. (2009). Development, characterization and cross-species/genera transferability of EST-SSR markers for rubber tree (Hevea brasiliensis). Mol. Breeding, 23 (1), 85-97.
Freitag, H. (1997). Salsola L. (Chenopodiaceae). In: Flora Iranica. Akadesche Druck-u, Verlagsanstalt, Graz, pp. 154-255.

Gasic, K., Han, Y., Kertbundit, S., Shulaev, V., Lezzoni, A. F., Stover, E. W. Bell, R. L., Wisniewski, M. E., Korban, S. S. (2009). Characteristics and transferability of new apple EST-derived SSRs to other Rosaceae species. Mol. Breeding., 23 (3), 397-411.

Giraldo, E., Viruel, M. A., Lopez-Corrales, M., Hormaza, J. I. (2005). Characterisation and cross-species transferability of microsatellites in the common fig (Ficus carica L.). J. Hortic. Sci. Biotech., 80 (2), 217-224.

González-Martínez, S. C., Robledo-Arnuncio, J. J., Collada, C., Diaz, A. Williams, C. G., Alia, R., Cervera, M. T. (2004). Cross-amplification and sequence variation of microsatellite loci in Eurasian hard pines. Theor. Appl. Genet., 109 (1), 103-111.

Grubov, V. I. (1980). Family Chenopodiaceae. [Грубов В. И. Семейство Mapeвые (Chenopodiaceae)]. In: Plant Life [Жизнь растений]. Education, Moscow, pp. 374-382 (in Russian).

Hammer, O., Harper, D. A. T., Ryan, P. D. (2001). PAST: Paleontological statistics software package for education and data analysis. Palaeontol. Electron, 4 (1), 9.

Huson, D. H., Bryant, D. (2006). Application of phylogenetic networks in evolutionary studies. Molec. Biol. Evol., 23 (2), 254-267.

Komarov, V. L. (1936). Flora of the USSR [Комаров В. Л. Флора СССР]. Science, Leningrad (in Russian).

Kumar, S., Stecher, G., Tamura, K. (2016). MEGA7: Molecular Evolutionary Genetics Analysis version 7.0 for bigger datasets. Molec. Biol. Evol., 33 (7), 1870-1874.

Kurochkina, L.Ya. (2003). Psammofit desert shrub [Курочкина Л.Я Псаммофитнокустарниковые пустыни]. In: Akzhigitova, N. I., Brekle, Z. V., Volkova, E. A. Geography of Kazakhstan and Central Asia (Within the Desert Region) [Акжигитова Н.И., Брекле З.В., Волкова Е.А. Ботаническая география Казахстана и Средней Азии (в пределах пустынной области)]. Science, St. Petersburg. pp. 83-92 (in Russian).

Larin, I. V., Agababjan, Sh. M., Rabotnov, T. A., Ljubskaja, A. F, Larina, V. K., Kasimenko, M. A. (1951). Feed Plants of Hayfields and Pastures of the USSR [Ларин И. В., Агабабян Ш. М., Работнов Т. А., Любская А. Ф., Ларина В. К., Касименко М. А. Кормовые растения сенокосов и пастбиш СССР]. State Publishing House of Agricultural Literature, Moscow. 947 pp. (in Russian).

Long, Y., Zhang, J., Tian, X., Wu, S., Zhang, Q., Zhang, J. (2014). De novo assembly of the desert tree Haloxylon ammodendron (CA Mey.) based on RNA-Seq data provides insight into drought response, gene discovery and marker identification. BMC Genomics, 15 (1), 1-11.

McGray, H. G., Ayres, D. R., Sloop, C. M., Lee, A. K. (2008). Beta SSR loci cross-amplify in five Salsola taxa. Mol. Ecol. Resour., 8 (3), 608-611.

Metsalu, T., Vilo, J. (2015). ClustVis: a web tool for visualizing clustering of multivariate data using Principal Component Analysis and heatmap. $\mathrm{Nu}$ cleic Acids Res., 43 (W1), W566-W570.

Milic, D., Lukovic, J., Zoric, L., Vasin, J., Ninkov, J., Zeremski, T., Milic, S. (2013). Halophytes relations to soil ionic composition. J. Serb. Chem. Soc., 78 (8), 1259-1268

Morenko, M. O. (2007). Halophytes of Altai mountainous system by example of family Chenopodiaceae [Моренко М. О. Галофиты Алтайской горной системы на примере семейства Маревые (Chenopodiaceae)]. Bulletin of Tomsk State University [Вестник Томского государственного университета], 298, 222-223 (in Russian).

Mosyakin, S. L. (2003). Salsola Linnaeus. Flora of North America North of Mexico, 4, 398-403.

Pallas, P. S. (1771). Reise durch verschiedene Provinzen des Russischen Reichs. Kayserliche Academie der Wissenschaften, St. Petersburg (in German). 504 pp.

Pavlov, N. V. (1960). Flora of Kazakhstan [Павлов Н. В. Флора Казахстана]. Science, Alma-Ata (in Russian). 
Peakall, R., Smouse, P. E. (2006). GENALEX 6: genetic analysis in Excel. Population genetic software for teaching and research. Mol. Ecol. Notes., 6, 288-295.

Peakall, R., Smouse, P. E. (2012). GenAlEx 6.5: genetic analysis in Excel. Population genetic software for teaching and research - an update. Bioinformatics, 28, 2537-2539.

Popova, O. A (2015). Node structure of some species of the genera Salsola L. and Anabasis L. (Chenopodiaceae) and significance of this characteristic for systematics [Попова О. А. Строение узла некоторых видов родов Salsola L. и Anabasis L. (Chenopodiaceae) и значение этого признака для систематики]. Scientific Notes of the Transbaikal state University. Series: Biological Sciences [Ученые записки Забайкальского государственного университета. Серия: Биологические науки], 60 (1), 31-36 (in Russian).

Pyankov, V. I., Artyusheva, E. G., Edwards, G. E., Black, Jr. C. C., Soltis, P. S. (2001). Phylogenetic analysis of tribe Salsoleae (Chenopodiaceae) based on ribosomal ITS sequences: Implications for the evolution of photosynthesis types. Amer. J. Bot., 88 (7), 1189-1198.

Qin, Y., Li, M., Cao, Y., Gao, Y., Zhang, W. (2017). Molecular thresholds of ITS2 and their implications for molecular evolution and species identification in seed plants. Sci. Rep., 7 (1), 1-8.

Rozas, J., Ferrer-Mata, A., Sánchez-DelBarrio, J.C., Guirao-Rico, S., Librado, P., Ramos-Onsins, S. E., Sánchez-Gracia, A. (2017). DnaSP 6: DNA sequence polymorphism analysis of large data sets. Mol. Biol. Evol., 34 (12), 3299-3302.

Ryan, F. J., Ayres, D. R. (2000). Molecular markers indicate two cryptic, genetically divergent populations of Russian thistle (Salsola tragus) in California. Can. J. Botany, 78 (1), 59-67.

Saitou, N., Nei, M. (1987). The neighbor-joining method: A new method for reconstructing phylogenetic trees. Mol. Biol. Evol., 4 (4), 406-425.

Shujskaja, E. V., Toderich, K. N. (2013). Isoenzymatic polymorphism in annual species of Salsola section Kali (Salsola aperta, S. paulsenii, S. pestifer and S. sogdiana) [Шуйская Е. В., Тодерич К. Н. Полиморфизм белков у однолетних видов Salsola секции Kali (Salsola aperta, S. paulsenii, S. pestifer и S. sogdiana)]. Bulletin of Bashkir University [Вестник Башкирского университета], 18 (2), 378-382 (in Russian).

Sokolov, S. Ja., Svjazeva, O. A., Kubli, V. A. (1980). Areas of Trees and Shrubs of the USSR [Соколов С. Я., Связева О.А., Кубли В.А. Ареальи деревьев и кустарников СССР]. Science, Leningrad (in Russian).

Suhorukov, A. P. (2007). Horological method in solving problems of phylogeny and systematics of Eurasian representatives of the Chenopodiaceae family [Сухоруков А. П. Хорологический метод в решении проблем филогенеза и систематики евразийских представителей семейства Chenopodiaceae]. Arid. Ecosyst. [Аридные экосистемы], 13 (32), 19-33 (in Russian).

Toderich, K. N., Popova, V. V., Aralova, D. B., Gismatulina, L. G., Rekik, M., Rabbimov, A. R. (2016). Halophytes and salt tolerant forages as ani- mal feed at farm level in Karakalpakstan [Тодерич К.Н., Попова В.В., Аралова Д.Б., Гисматулина Л.Г., Рекик Мурад и Раббимов А.Р. Галофиты и солеустойчивые растения в качестве корма животных на уровне фермерских хозяйств в Каракалпакстане]. Tashkent (in Russian).

Turuspekov, Y., Abugalieva, S. (2015). Plant DNA barcoding project in Kazakhstan. Genome, 58 (5), 290.

Turuspekov, Y., Genievskaya, Y., Baibulatova, A., Zatybekov, A., Kotuhov, Y., Imanbayeva, A., Abugalieva, S. (2018). Phylogenetic taxonomy of Artemisia L. species from Kazakhstan based on matK analyses. Proceed. Latv. Acad. Sci. Sect. B., 72 (1), 29-37.

Wen, Z. B., Zhang, M. L., Zhu, G. L., Sanderson, S. C. (2010). Phylogeny of Salsoleae s.1. (Chenopodiaceae) based on DNA sequence data from ITS, psbB-psbH, and rbcL, with emphasis on taxa of northwestern China. Plant. Syst. Evol., 288 (1-2), 25-42.

Westman, A. L., Kresovich, S. (1997). Use of molecular marker techniques for description of plant genetic variation. Biotechnol. Plant Gen. Res., $9-48$.

White, T. J., Bruns, M. E., Lee, S., Taylor, J. (1990). Amplification and direct sequencing of fungal ribosomal RNA genes for phylogenetics. In: Innis, M. A., Gelfand, D. H., Sninsky, J. J., White, T. J. (eds.). PCR Protocols: A Guide to Methods and Applications. Academic Press, San Diego, pp. 315-322.

Yeh, F. C., Yang, R. C., Boyle, T. B. J., Ye, Z. H., Mao, J. X. (1997). PopGene, the user-friendly shareware for population genetic analysis. POPGENE, user-friendly shareware. Popul. Genet. Anal., 10, 295-301.

Yu, N., Wei, Y. L., Zhang, X., Zhu, N., Wang, Y. L., Zhu, Y., Zang, H. P., Li, F. M., Yang, L., Sun, J. Q., Sun, A. D. (2017). Barcode ITS2: A useful tool for identifying Trachelospermum jasminoides and a good monitor for medicine market. Sci. Rep., 7 (1), 1-9.

Yumak, H., Ucar, T., Seyidbekiroglu, N. (2010). Briquetting soda weed (Salsola tragus) to be used as a rural fuel source. Biomass. Bioenerg., 34 (5), 630-636.

Zhang, J., Zhao, P., Zhao, J., Chen, G. (2018). Synteny-based mapping of causal point mutations relevant to sand rice (Agriophyllum squarrosum) trichomeless 1 mutant by RNA-sequencing. J. Plant Physiol., 231, 86-95.

Zvolinskij, V. P., Tumanjan, A. F., Vvedenskij, V. V. (2013). Restoring and improving of productivity degraded rangeland ecosystems in arid zone of the Caspian sea region [Зволинский В. П., Туманян А. Ф., Введенский В. В. Восстановление и повышение продуктивности деградированных пастбищных экосистем в аридной зоне Прикаспия]. Theoretical and Applied Problems of Agro-Industrial Complex [Теоретические и прикладные проблемы агропромышленного комплекса], 16 (3), 26-29 (in Russian).

Received 18 August 2020

Accepted in the final form 23 September 2020

\section{MIKROSATELĪTU MARĶIERU STARPĢINŠU PĀRNESES IESPĒJA UN FILOĢENĒTISKS TRĪS SALSOLA SUGU IZVĒRTĒJUMS RIETUMKAZAHSTĀNĀ}

Tika pētīta ğenētiskā daudzveidība trīs sugu: Salsola arbuscula Pall., Salsola arbusculiformis Drob. un Salsola chiwensis M. Pop. augiem, kuri tika ievākti Rietumkazahstānā. Trīspadsmit no 26 novērtētiem mikrosatelītu markiieriem izrādījās piemēroti ğenētiskās daudzveidības noteikšanai visām trim minētām sugām. Secināts, ka polimorfi mikrosatelītu markiieri ir efektīvi ğints Salsola ğenētiskās daudzveidības izvērtējumam. 